valsts sabiedrība ir aizspriedumaina simbolu līmenī - mums vieglāk ielaist svešinieku savā gulamistabā, grūtāk uzticēt kādu no nacionālās identitātes simboliem, teiksim - nest dziesmusvētku karogu, kā tas bija jautāts pētījumā. Viena lieta ir to nojaust, pavisam cita - pierādīt. Biznesa augstskolas Turība veiktais pētījums to ir pierādījis, A. Pētersons savā monogrāfijā zinātniski pamatojis.

Monogrāfija vairs nav nopērkama - tā pieejama vien bibliotēkās. Darbs tomēr pelnījis, lai ar to iepazītos plašāks lasītāju pulks. Gan jau profesors A. Pētersons un, nešaubos, arī vēl kāds no mācībspēkiem to izmanto mācību procesā. Laikā, kad grāmatas lasa arvien mazāk, tas nozīmē, ka grāmatai ir l,oti paveicies - tā dzīvo. Gribētos cerēt, ka arī šīs pārdomas par A. Pētersona monogrāfiju rosinās viṇu padomāt par dažām lietām un tās tiks ja ne uzrakstītas, tad pārspriestas ar studentiem.

Nobeigumā vēl pārdomas, kuras raisīja šogad notikušais Latvijas vēsturnieku 2. kongress. Kongresā piedalījās un uzstājās gan A. Pētersons, gan šo rindu autors. Diskusijās tika skarts jautājums par latviešu vēsturnieku monogrāfijām, kurās dominē germāṇu jeb vācu skola - smaga valoda, rūpiga argumentācija, neskaitāmas atsauces uz citu autoru darbiem. Šādas monogrāfijas tikpat kā nav iespējams tulkot ang̣̣u valodā, kurā pieņemts viegls esejisks rakstīšanas stils. A. Pētersona monogrāfija nav pētījums vēsturē, tomēr vēstures tur ir daudz. Varētu atzīmēt, ka tas, kā raksta šis autors, ir vidusceḷ̌s starp abām skolām - anglosakšu un germāṇu. Varbūt viņam izdodas atrast ceḷu, kā apvienot labāko no abām skolām, to arī novēlu.

\title{
CILVĒKS AR VALIDITĀTI
}

Ilva Skulte, Dr. philol., Rīgas Stradiņa universitātes asociētā profesore

Viens no Latvijas mediju politikas nesenajiem veidotājiem, tagad partijas Progresīvie līderis Roberts Putnis publicējis grāmatu ES esmu starp jums: Cilvēks ar invaliditāti un sabiedriskie mediji ([2017] Rīga : Vesta-LK), kas ne tikai parāda vina kompetenci mediju, sabiedrības un demokrātijas laukā, bet ir arī sava veida vērtību deklarācija. Tajā viņš detalizēti pievēršas sabiedriskajiem medijiem kā instrumentam cilvēku ar invaliditāti dziḷākam akceptam un integrācijai sabiedrībā. Nelielās grāmatiņas izdevēji lakoniski, bet niansēti risinājuši vāka dizaina jautājumu (mākslinieks Dmitrijs Markovs). Aiz melnbaltās lapas stilizētajiem "uzplēsumiem" vīd daudzkrāsainība, un šie vizuālie elementi ne tikai uzrunā redzi, bet arī liek mobilizēt taustes uztveri un apzināties, cik maz, ja neesi īpaši apguvis, varētu turēt līdzi, piem., Braila lasītājam.
Diemžēl ne viss izdevies vienlīdz labi. Jau grāmatas nosaukums par tā saturu nepasaka gandrīz neko, tiesa, apakšvirsraksts paskaidro, bet arī tas būtu veiksmīgāks, ja dotu mājienu par jautājuma nostādni, nevis savestu kopā divus jēdzienus (kurus cilvēki dzirdējuši pietiekami, lai tie neraisītu interesi, pat ja izpratnes par tiem lielākajā daḷā sabiedrības principā nav). Līdzīgi varētu aprakstīt arī grāmatas saturu.

Nevar noliegt, ka tā rakstīta par sociāli svarīgu, Latvijas mediju politikā aktuālu un vienlaicīgi filozofiski interesantu un nebūt ne vienkāršu tēmu. Turklāt rakstīta ar zināšanām, misijas apzinu un apzinoties rakstītā vērtìbu un nozīmi. Apsveicami arī, ka vairākās grāmatas daḷās izklāstītās domas, idejas un teorētiskie modeḷi ir pietiekami saturiski izvērsti un dzilii, lai latviski izdoto grāmatu klāstā aizpildītu 
mazu daḷiņu no milzīgā tukšuma. Grāmatai ir arī potenciāls kḷūt par pārdomu, mācīšanās un diskusijas iemeslu. Tomēr, visticamāk, tā par tādu nekḷūs. Tas galvenokārt tāpēc, ka autors nav papūlējies savest visus savus stāsta pavedienus vienkopus, nav līdz galam atradis pamatu argumentiem, vispār nav skaidri l̦āvis saprast, kādām tēzēm īsti galvenie argumenti tiks meklēti. Visjēdzīgāk būtu argumentēt, kādēḷ kaut kas (kas tieši un kā!) būtu jāmaina tieši Latvijas sabiedriskajos medijos, bet līdz tam īsti Roberts Putnis tā arī nenonāk. Tā vietā viņš dod (loti interesantu, lai gan dažkārt nepamatoti vienpusīgu) pārskatu par trīs atšķirīgām jomām - invaliditāti, mediju lomu sociālās realitātes konstruēšanā un Vācijas sabiedriskajiem medijiem.

Tiesa gan, invaliditātes pavediens izvilkts cauri arī abām divām citām jomām. Turklāt darbs, kura pamatā ir Vidzemes Augstskolā aizstāvētais bakalaura darbs, strukturēts, kā jau bakalaura darbam pienākas - teorētiskā daḷa, metodes apraksts, rezultāti, diskusija un secinājumi. Tomēr tieši ši "uzliktā" struktūra modina aizdomas par šì visnotal cienījamā teksta funkcionālo daudzveidību. Tas nav vienkārši eksperta redzējums par noteiktu problēmu savā kompetences laukā, nav tikai pētījums, kas veikts bakalaura darba iegūšanai. Nav arī tikai "aicinājums sabiedrībai neizslēgt no sava vidus cilvēkus ar invaliditāti”, kā savā priekšvārdā, tulkojot virsrakstu, norāda Eiropas Savienības tiesnesis Egils Levits (13. lpp.). Kā darba galveno vērtību viņš pamatoti izcel pavisam ko citu - skaidru un labi strukturētu pārskatu par sabiedriskajiem medijiem kā nozīmīgu demokrātijas balstu, medijiem konstruējot sociālo realitāti.

Grāmatas pirmā lielā nodaḷa veltīta invaliditātes koncepta aplūkojumam. Lai arī filozofisko pamatnostādņu vietā autors vispirms negaidīti dod ieskatu par to, kā invaliditātes uztveri ietekmē dažāds vēsturiskais konteksts, kopumā viṇam izdodas sasniegt mērḳi un, salīdzinot mūsdienu skatījuma paradigmas, sniegt dialektisku pārskatu par invaliditātes izpratni mūsdienās dažādu modeḷu - rehabilitācijas jeb medicīniskā, sociālā un kultūras - savijumā un pretnostatījumā. R. Putnis seko atziņām galvenokārt vācu autoru - G. Klērkesa, A. Valdšmitas, M. Šolca un D. Radkes - rakstos un skatās uz problēmu sociālo normu un to izmaiņu kontekstā. Nodaḷas noslēgumā autors atzīst, ka tomēr nav iespējams uz šo atzinu pamata "visaptveroši un noslēdzoši definēt invaliditāti” (56. lpp.), kas, manuprāt, nav vērtējams kā problēma, taču skaidrs, ka neatvieglo darbu ne regulatoram, ne pētniekam.

Seko nodala Mediji un invaliditātes sociālā normativitāte, kurā autors galvenokārt pievēršas mediju lomai (demokrātiskā) sabiedrībā, apraksta sociālās realitātes konstruēšanu, ietekmi un politiku, un sabiedrību, atkal lielākoties balstoties uz vācu komunikācijas teorijas tradīciju (N. Lūmans, V. Šulcs u. c.) un sīkāk pievēršoties darba kārtības noteikšanas un klusēšanas spirāles model̦iem. Atsevišķa apakšnodaḷa veltīta mediju lomai invaliditātes, ar to saistīto normu un nostāju pret invaliditāti konstruēšanā, kopumā parādīiti mehānismi, kuru ietvaros mediji piedalās 1) invaliditātes sociālā akcepta normu veidošanā un 2) cilvēku ar invaliditāti sociālās mijiedarbības veidošanā. Izaicinājums mediju politikas un stratēǵiju veidotājiem ir ne vien iesakņojušos skatījumu dekonstrukcija, bet arī, piem., atšķirības starp invaliditātes veidiem (un līdz ar to atbalsta veidiem, ko medijs var sniegt), kā arī cilvēku ar invaliditāti pašu iesaistīšana mediju darbā. Kopumā nodaḷa piedāvā rūpīgu un detalizēti izstrādātu modeli tālākajam pētījumam, kurā ņemti vērā un izvērtēti ḷoti dažādi invaliditātes, mediju un sabiedrības mijiedarbības aspekti.

Nākamās nodal̦as reprezentē pašu pētījumu. Neapšaubāmi, te daudz vērtīgu, rūpīgi formulētu atziṇu, kā arī sniegts izsmeḷošs pārskats par Vācijas sabiedrisko mediju regulējumu un invaliditātes jautājumu vietu dažādu š̄s sazarotās sistēmas raidorganizāciju stratēǵijās. Tomēr tieši š̄s nodaḷas rada arī daudz jautājumu. Piem., kaut arī vesela nodaḷa ar nosaukumu Metode veltìta diskursa analīzes (M. Fuko + J. Hābermāss) aprakstam par to, kā un attiecībā uz kādiem materiāliem (un kādē l̦ tieši šādi un tādiem materiāliem) š̄ metode tiks lietota, skaidrība nerodas - modelis, analizēto materiālu izlase un mērḳi paliek tikai ḷoti aptuveni nojaušami. Tāpat nav skaidrības arī par balansu starp invaliditātes veidiem un to, cik lielā mērā pārskats ir par visiem invaliditātes veidiem un vai secinājumi attiecas uz tiem visiem. Piem., daudzkārt uzsvērta pozitīvā prakse (nav gan 
skaidrības, kā izpētīts, cik precīzi organizāciju normatīvie dokumenti tiek realizēti praksē) raidījumu subtitrēšanā, bet mazāk runāts par audio formātiem neredzīgajiem un vājredzīgajiem skatîtājiem, "vieglo" valodu vai citiem, moderno tehnologiju piedāvātiem risinājumiem. Tāpat nav analizētas zināmo risinājumu priekšrocības un trūkumi, kā arī izaicinājumi, ko tie sagādā raidorganizācijām, ieskaitot finansiālos izaicinājumus. Diskursa analīze pētījuma daḷā nespēj dod neko principiāli interesantu un jaunu salīdzinājumā ar teorētiskajām nodaḷām.

Diemžēl autors nav skaidrojis arī šo nodaḷu vietu kopīgajā darba mērķu sasniegšanas kontekstā. Nav skaidrs, kā aprakstītais Vācijas sabiedrisko mediju regulējums tieši nodrošina cilvēku ar invaliditāti integrāciju. Nav skaidrs, kā izpētītais korelē ar Latviju vai attiecināms uz citām valstīm - daudz detalizēta materiāla, kas nenoliedzami ir interesants, bet nav pierādīts, ko tas dod tieši šai tēmai vai, formulējot citādi, kā, piem., nosacījumi, kas radīti Vācijas sabiedrisko mediju sistēmā, invaliditātes sociālās konstruēšanas un cilvēku ar invaliditāti iesaistīšanas kontekstā varētu dot labāku rezultātu nekā morāli attīstīta, iejūtīga, godīga, solidāra un apzinīga mediju darbinieka intuitīvi pašregulatīivais darbs.

Tādēḷ arī secinājumi sanākuši vispārīgi un nekonstruktīvi, lai arī pārskatāmi strukturēti atsevišķi nostāju, mediju un specifiski arī sabiedrisko mediju līmenī. Tie formulēti idealizēti normatīvā diskursā - kā "vajag", nevis kā "ir" - un netiek līdz līmenim, kurā parādītos, kas "nepieciešams, lai būtu". Mazliet nepārdomāts liekas, piem., pēdējais secinājums: "Žestu valodai sabiedrisko mediju saturā jāienem valsts valodai līdzvērtīgas pozīcijas." N̦emot vērā, cik sarežǵīta ir šādu pozīciju "noturēšana", un ņemot vērā, ka vienlīdz nozīmīgi tad būtu pārstāvēt ar līdzīgām pozīcijām arī citus invaliditātes veidus, domāju, ka risinājumiem šajā jomā būtu jābūt mazāk regulatīviem, bet drīzāk orientētiem uz mediju vadības un visu profesiju darbinieku vērtībām un izpratni. Šo izpratni noteikti veicinātu arī R. Putna grāmatas apgūšana, kā arī īpašs atbalsts tālākiem pētījumiem par sabiedrisko mediju organizācijas principiem, saturu un diskursu kopumā attiecībā uz cilvēkiem ar invaliditāti.

\title{
KASKADIERIS NEIZPILDĀMĀKAI EPIZODEI
}

\author{
Raivis Bičevskis, Dr. phil., LU asociētais profesors
}

Vācu filozofs Odo Markvards (19282015), kurš sevi pieskaitīja pēckara skeptiskās paaudzes pulkam, vienā no saviem tekstiem, kas veltīts mūsdienu zinātņu un filozofijas liktenim, izsakās, ka filozofs vienmēr bijis brīvs pēddzinis, kurš savos pētījumos med̄̄ it visur un šḳērso visdažādāko disciplīnu, zinātnuu, mākslu un ikdienas dzīves jomu robežas. Tāpēc ekspertu kultūras laikmetā ir grūti filozofu novietot un "noḳert" un vina teikto klasificēt. Sekas tam ir jau kopš Platona vēstulēm pazīstamie filozofijas vērtējumi, kuru skala sniedzas no apbrīnas līdz nicinājumam un plecu raustīšanai. Taču ir tā, ka ekspertu kultūrā reiz pienāk brīdis, kad eksperti pieklust vai rausta plecus nevis tāpēc, ka filozofu izteikumi būtu dīvaini un pārāk neieklaujami, piem., reālpolitikas vai sociopsihologijas pielietojumā, bet gan tāpēc, ka pati realitāte, paši fenomeni, par kuriem ir runa, ir pārāk kompleksi vai vispār netverami, lai gan piln̄̄gi un nepārprotami "reāli”. Tad, saka U. Markvards, filozofs parādās kā kaskadieris neizpildāmākai epizodei, kuras paveikšanu 